\title{
The Settlement of the Bidding Contest for a Public Task Implemented by Non-Governmental Organisations and Public Benefit Entities Without the Possibility of Initiating an Appeal Procedure
}

\section{Introduction}

The direct inspiration to address the lack of legal grounds for initiating the appeal procedure related to the settlement of open bidding contests for the implementation of public tasks are the statements of representatives of non-governmental organisations and other public benefit entities referred to in Article 3(3) of the Act of 24 April 2003 on Public Benefit Activity and Volunteer Work ${ }^{1}$ (hereinafter: APBAVW).

In the opinion of these entities, the prevailing perspective is that of disproportion in cooperation of public benefit entities with public administration bodies in the performance of public tasks. What is meant here is, in particular, the lack of legal remedies, especially the impossibility of being able to appeal against the announced result of the contest.

The Act on Public Benefit Activity and Volunteer Work introduces the concept of public benefit activity defined as socially useful activity, performed by authorised entities which the legislator has recognised as legal persons or organisational units without legal personality, which are granted legal capacity by a separate act, including foundations and

1 Consolidated text: Journal of Laws of 2019, item 688. 
associations, not being entities of the public finance sector and not operating on a for-profit basis (Art. 3(2) APBAVW). In addition, public benefit activity may be performed, inter alia, by: (1) legal persons and organisational units operating on the basis of the provisions governing the relationship between the State and the Catholic Church and other churches in the Republic of Poland; (2) associations of local government units; (3) social cooperatives; and (4) public limited companies and limited liability companies (Art. 3(3) APBAVW).

Undoubtedly, the enactment of the APBAVW is a major achievement in the systemic regulation of the relationships between public administration and non-governmental organisations and public benefit entities, because for the first time in Polish legislation the principles of cooperation between these entities and the procedure of commissioning public tasks have been fundamentally regulated. The entities authorised to perform statutory public tasks within the meaning of the APBAVW are entities authorised to perform public benefit activities. According to the Voivodship Administrative Court in Kielce, in its judgment of 24 May 2016, "in order to apply for being recognised as a public benefit entity, it should be e.g. a non-governmental organisation, and not the other way round."2 This is also confirmed by A. Pakuła, who believes that all the entities indicated by the legislator are defined as entities entitled to perform public benefit activities, which is a broader concept than that of non-governmental organisations. ${ }^{3}$ Therefore, with a view to ensuring the maximum transparency of the study, the author uses the term "public benefit organisations" (hereinafter: PBO) for entities performing public tasks.

The study will comprise the following assertions:

1) The public administration body is the decisive entity for cooperation with the PBO;

2 Judgment of the Voivodship Administrative Court in Kielce of 24 May 2016, case ref. I SA/ Ke 239/16, Legalis no. 1476147.

3 A. Pakuła, W kwestii prywatyzacji organizacyjnych form realizacji zadań publicznych $w$ trybie ustawy o działalności pożytku publicznego i wolontariacie na przykładzie pomocy społecznej, in: J. Blicharz, Prawne aspekty prywatyzacji, Warszawa 2012, p. 129. 
2) The open contest procedure is not based on the provisions of the Act of 14 June 1960 on the Code of Administrative Procedure ${ }^{4}$ (hereinafter: CAP);

3) In the course of the contest procedure there is no provision which would constitute a substantive law basis for issuing administrative decisions or taking other actions referred to in art. 3(2)(4) of the Act of 30 August 2002 on the Administrative Court Procedure $^{5}$ (hereinafter: AACP) by a public administration body or an appointed contest committee;

4) The settlement of a contest is not an administrative decision.

\section{The Programme of Cooperation with Public Benefit Organisations}

Article 5(1) and (2) APBAVW provides that public administrations bodies shall perform their activities in the sphere of the public tasks referred to in Article 4 APBAVW in cooperation with the PBOs. This cooperation may take financial and non-financial forms. With regard to the current deliberations, financial forms play an important role. The essence of these is that they require the announcement of an open contest (Article 11(2) APBAVW), the procedure of which is subject to further debate.

One of the financial forms is support for public tasks (Article 11(1)(1) APBAVW) and another is delegation (Article 11(1)(2) APBAVW). The delegation of tasks is a form of cooperation in which $100 \%$ of the funds (subsidies) for the implementation of the task is transferred (Article 4(1) APBAVW), while support is the transfer of part of the funds (subsidies) to co-finance the task (Article 4(2) APBAVW). According to the jurisprudence of administrative courts, the purpose of the bidding contest is not to "grant support" but to select the entity which will per-

4 Consolidated text: Journal of Laws of 2020, item 256.

5 Consolidated text: Journal of Laws of 2019, item 2325. 
form the public task specified in the announcement. ${ }^{6}$ The views of the judiciary are also shared by J. Kopyra, who claims that it is the implementation of specific public tasks that is financed and co-financed, and not the entities that perform the tasks. ${ }^{7}$ J. Blicharz also considers subsidising the implementation of the task, and not subsidising the organisation, to be the only possible way to transfer funds from the local government budget. ${ }^{8}$

Prior to the announcement of the contest, the sine qua non condition is the adoption by the commune council, district council or voivodship assembly, respectively, of a programme of cooperation with the PBOs. What is important is that the draft programme is subject to obligatory consultations, because, as indicated in Art. 5(2)(3) and (4) APBAVW, cooperation of local government with the PBOs is to take the form of, inter alia, consultation of draft normative acts in the area of the organisation's statutory activity and in the area of public tasks, including the resolution on the cooperation programme. The judgment of the Voivodship Administrative Court in Wrocław of 11 June 2013 states that "regardless of whether or not in the course of the consultation referred to in Art. 5a APBAVW, the indicated organisations and entities express their opinions, whether or not the submitted opinions are binding, the provision - "a decision-making body of a local government unit shall adopt [the programme] after consultation" - has the power of a condition without which the activity of the commune's decision-making body is not only defective but, in the absence of circumstances justifying the impossibility to seek consultation, it is invalid." In turn, A. Olejnic-

6 Ruling of the Voivodship Administrative Court in Szczecin of 31 August 2015, I SA/ Sz 866/15, Lex no. 1787241, Ruling of the Supreme Administrative Court in Warsaw of 14 December 2016, I OSK 2546/16, Lex no. 2205576, Ruling of the Voivodship Administrative Court in Kraków of 16 May 2017, III SA/Kr 292/17, Lex no. 2285423.

7 J. Kopyra, Ustawa o działalności pożytku publicznego i o wolontariacie. Komentarz, Warszawa 2005, p. $371 \mathrm{ff}$.

8 J. Blicharz, Komentarz do art. 13 ustawy o działalności pożytku publicznego i o wolontariacie, in: J. Blicharz, Ustawa o działalności pożytku i o wolontariacie, Lex no. 2012.

9 Judgment of the Voivodship Administrative Court in Wrocław of 11 June 2013, case ref. III SA/Wr 124/13, Lex no. 1330073. 
zak points out that the failure of a local government unit (hereinafter: LGU) to carry out consultations prior to the adoption of the cooperation programme, or carrying them out in a manner inconsistent with the rules, means that its adoption is defective, by depriving the PBOs of the right to influence the shape of the rules in force, in particular with respect to the support and delegation of public tasks. ${ }^{10}$

It should be noted that PBOs only take part in the process of adopting normative acts without the possibility to decide on the scope of tasks and the amount of funds allocated for their implementation. The decisive entity is the public administration body, as it has the authority to finally announce the result of the bidding contest and to control the execution of the tasks. A PBO may only seek to expand cooperation activities by presenting to the public partner the benefits of cooperation and more effective and economical implementation of the tasks assigned to the public administration body.

The cooperation programme is a document that should provide comprehensive information on the planned directions and scope of cooperation. It may take the form of an annual or multiannual programme. An annual programme shall be adopted by the decision-making body of the LGU by 30 November ${ }^{11}$ of the year preceding the financial year. The indicated deadline is an instructional one, but it does not mean that the decision-making bodies may evade the adoption of an appropriate resolution. It means, however, that the failure to observe the specified deadline, although it undoubtedly constitutes an infringement of the law, does not give grounds for declaring the resolution invalid and does not deprive the decision-making body of its competence to adopt such a resolution. Thus, the adoption of a resolution on the programme after

10 A. Olejniczak, Skutki braku konsultacji programu współpracy z organizacjami pozarzqdowymi i pożytku publicznego, 2016, Legalis, accessed on 21 May 2020.

11 The deadline of 30 November is related to the requirement of Art. 238(1) of the Public Finance Act of 27 August 2009 (hereinafter: PFA) obliging the executive body of a local government unit to draw up and submit a draft budget resolution by 15 November of the year preceding the financial year. 
the lapse of the statutory deadline, although it is an infringement of the law, does not constitute, in the light of the interpretation principles of purposefulness, a material infringement giving rise to declaring such a resolution invalid, due to its subject matter and nature, as well as the effects of considering the deadline to fall under substantive law. ${ }^{12}$

The cooperation programme, as a rule, is strategic in nature and should contain norms setting out the directions of action by the LGU and PBO. This is confirmed by the judgment of the Voivodship Administrative Court in Wrocław of 7 July 2011, in which it was stated that "a programme of cooperation with non-governmental organisations should include legal norms of a programmatic nature, in the form of norms setting out tasks." ${ }^{13}$ The programme is designed to be a stimulator of joint action for the best possible satisfaction of social needs.

\section{The Open Bidding Contest Procedure, Tender Content and its Examination}

Art. 13 APBAVW provides that a public administration body intending to commission a public task shall announce an open contest. Most often it results from the initiative of a public administration body, however, according to the content of Art. 12 APBAVW, the PBOs also have the right to apply for the implementation of the task. Then the administration body is obliged to consider the advisability of the task within one month, and above all to take into account the following: (1) the extent to which the tender corresponds to the priorities of the public tasks; (2) ensuring high quality of task execution; (3) the resources available for specific tasks; (4) types of specific tasks; and (5) the advantages of

12 Judgment of the Supreme Administrative Court of 24 November 2011, case ref. II OSK 2107/11, Legalis no. 480582.

13 Judgment of the Voivodship Administrative Court in Wrocław of 7 July 2011, case ref. III SA/Wr 243/11, Lex no. 1154645. 
the public task being performed by the bidder. ${ }^{14}$ Subsequently, the public authority is obliged to inform the entity of its decision. This decision only provides information about the position of the administrative body, and it does not have the features of an administrative act ${ }^{15}$ within the meaning of CAP. This view is sustained by N. Kowal ${ }^{16}$, who believes that it is not possible to immediately commission the implementation of the public task to the entity that took the initiative. The initiative cannot replace an open bidding contest procedure. ${ }^{17}$

The deadline for the submission of tenders may not be shorter than 21 days from the last announcement (Article 13(1) APBAVW), which is undoubtedly intended to enable equal access and proper preparation of the tender by PBOs interested in carrying out the tasks..$^{18}$ The announcement of the contest contains a set of guidelines to be followed when applying for public tasks. In accordance with Article 13(2) APBAVW, the announcement shall contain information on: (1) the type of the task; (2) the amount of public funds allocated to the task; (3) the rules for subsidising; (4) the deadlines and conditions for the implementation of the task; (5) the deadline for the submission of tenders; (6) the time limit, procedure and criteria used for the selection of tenders; and (7)

14 Art. 12(2)(1) APBAVW and P. Kledzik, Działalność organizacji pozarzqdowych na rzecz realizacji celów publicznych, Warszawa 2013, p. 158.

15 H. Izdebski, Ustawa o działalności pożytku publicznego i o wolontariacie. Komentarz, Warszawa 2003, p. 56; N. Kowal, Tworzenie i rejestracja pożytku publicznego. Komentarz, Kraków 2005, p. 47.

$16 \mathrm{~N}$. Kowal argues that such a position is supported by the fact that the administrative body informs only those concerned about the result of the contest, without delivering a copy of the relevant document, without giving a legal basis or justification and without providing guidance on the remedies available, the presence of the said elements being, pursuant to Article 107 CAP, a necessary feature of each administrative decision. This view shall be shared indirectly, since the direct reason for the exclusion of the form of an administrative decision seems to be the fact that the decision referred to in Article 12 APBAVW does not possess the attributes inherent in an administrative act.

17 P. Staszczyk, Ustawa o działalności pożytku publicznego i o wolontariacie. Komentarz, Warszawa 2013, p. 48.

18 N. Kowal, Komentarz do ustawy o działalności pożytku publicznego i o wolontariacie, in: Tworzenie i rejestracja organizacji pożytku publicznego, Zakamycze 2005, Legalis, accessed on 21 May 2020. 
the public tasks of the same type, as performed by the public administration body in the year of the open bidding contest and in the previous year, and the related costs, with particular regard to the amount of subsidies awarded to non-governmental organisations and entities referred to in Article 3(3) APBAVW.

The criteria for the evaluation of tenders should be established in such a way as not to exclude any category of PBOs. Moreover, as indicated in the judgment of the Voivodship Administrative Court of 8 May 2013, "the criteria of the contest should be known to all bidders in accordance with the principle of openness of public authority and the necessity to respect the constitutional principle of equal treatment. The rationale behind the substantive assessment to be made by the executive body in a particular case should therefore be specified so that they are not considered arbitrary or discriminatory as a result of unequal treatment."19

The elements which should constitute the components of tenders for the performance of a public task are listed in Article 14(1) APBAVW, which stipulates that the tender should include, in particular: (1) the detailed material scope of the public task proposed for implementation; (2) the time and place where the task is to be implemented; (3) the calculation of the expected costs of the public task; (4) information on the previous activities of the bidder in the scope of the task; (5) information about the material and human resources available to ensure the performance of the task, including the amount of funds obtained for the performance of the task from other sources; and (6) declaration of intent to perform the task against payment or free of charge.

Regardless of the above-mentioned calculation, the implementing provisions, in accordance with the authorisation contained in Article 19 APBAVW, comprise a framework model for the public task tender. ${ }^{20}$ The model has been included in the legal act, so it should be remem-

19 Judgment of the Voivodship Administrative Court in Wrocław of 8 May 2013, case ref. III SA/Wr 125/13, Lex no. 1330074.

20 Regulation of the Chairman of the Public Benefit Committee of 24 October 2018 (Journal of Laws of 2018, item 2055). 
bered that it is an integral part thereof. Voluntary preparation of the tender disqualifies the right to proceed to the substantive assessment stage. Prima facie the tender form seems to be understandable and easy to fill in, but in practice it can be complicated for PBOs. This view is also shared by R. Skiba. ${ }^{21}$

All tenders submitted to the contest are subject to assessment. It is usually made up of two stages: (1) formal assessment and (2) substantive assessment. The criteria for formal assessment ${ }^{22}$ shall be indicated in the contest announcement or in an annex thereto. If the formal criteria are not met, the tender is not subject to further evaluation. For example, the supervisory resolution of the Lubuskie Voivodship Governor indicated that if a tender is rejected due to formal defects, this makes it impossible to carry out further evaluation within the scope specified in Article 15(1) APBAVW. ${ }^{23}$ In addition, this provision provides that tenders are to be examined by a public authority in the light of the criteria set out in items $1-6$ of that article, and not by a contest committee. ${ }^{24}$ It should be considered whether, where formal deficiencies in the tenders have been found before the expiry of the time limit set for the submission of tenders, the PBOs, after having been notified, could effectively remedy the deficiencies identified.

It is noteworthy that in the case of administrative proceedings governed by the provisions of the CAP, or administrative court proceedings governed by the provisions of the AACP, submission of a plea containing formal deficiencies that can be remedied results in the obligation of the public administration body or the court to issue a summons to remedy these deficiencies within the prescribed time limit, under the pain of respectively: leaving the application without examination, or its rejec-

21 R. Skiba, Jak współpracować z administracjq publicznq, Warszawa 2004, p. 15.

22 Elements of the formal assessment criteria include i.a. the date of tender submission, completeness of the required attachments, submission of tenders in the appropriate form.

23 Supervisory resolution of the Lubuskie Voivodship Governor of 5 February 2015, case ref. NK-I.4131.20.2015 (Official Journal of the Lubuskie Voivodship of 2015, item 268).

24 Supervisory resolution of the Lubuskie Voivodship Governor of 18 February 2015, case ref. PN-II.4131.78.2015, Legalis no. 1180688. 
tion. Therefore, in case of an open bidding contest procedure, it would be appropriate to allow the PBOs to remedy the formal deficiencies until the deadline for the submission of tenders. It is worth noting at this point the ruling of the Supreme Administrative Court in Warsaw of 30 November 2011, in which the court pointed out that the APBAVW does not contain a provision which could constitute a substantive law basis for the administrative decisions, or other actions specified in Article 3(2)(4) AACP, being taken in the course of the contest procedure by the public administration body announcing the contest or the contest committee appointed by it. ${ }^{25}$ In addition, the ruling concludes that the administrative court has no jurisdiction to hear complaints against letters notifying of tender rejection and thus cannot review "procedural errors" made in the course of the open bidding contest.

It should be pointed out that, in Article 15(1) APBAVW, the legislator did not use the phrase "in particular" or any other equivalent phrase when listing the assessment criteria. This means that the public administration bodies announcing a contest may set the criteria themselves, provided that they are not contrary to the law. Undoubtedly, there are no grounds for the examination of a tender submitted by a PBO which does not meet the requirements specified in the act and the regulation.

According to J. Blicharz, any tender is also invalid if it does not meet any of the conditions set out both in the announcement and in the regulation on the model of tenders. ${ }^{26}$ When the tenders are examined with regard to the possibility of public task implementation by a PBO, consideration is given to the presented calculation of the costs of public task implementation, also in relation to the material scope of the task, the proposed quality of task implementation, and the qualifications of the persons who are going to be involved by the PBO in task implementation. In the case of support for the performance of a public task, the planned share of the PBO's

25 Ruling of the Supreme Administrative Court in Warsaw of 30 November 2011, case ref. II GSK 2022/11, Lex no. 1151678.

26 J. Blicharz, Komentarz do art. 18a ustawy o działalności pożytku publicznego i wolontariacie, in: Ustawa o działalności pożytku publicznego i wolontariacie, Lex 2012. 
own resources and those originating from other sources as well as in-kind and personal contributions shall be taken into account.

The substantive assessment pursuant to Article 15(2a) to (2f) APBAVW, as emphasised previously, is carried out by the contest committee appointed by the head of the commune or mayor. Pursuant to Article 15(2b) to (2d) APBAVW, the committee is composed of representatives of the executive body of the commune and representatives of the PBO. Persons having expertise in the field covering the scope of the public tasks concerned may also participate in the work of the committee, but only as advisors. The members of the committee are exempt from participation in the procedure if there are premises included in Art. 24 CAP aimed at ensuring impartial assessment. The obligation to set up a contest committee probably serves the following purposes: (1) to encourage transparency in the conduct of the open bidding contest; and (2) to increase the objectivity of settlements, though the regulations contained in Article 15(2a) to (2f) APBAVW in fact do not guarantee this. The contest committees do not select the winner of the contest but only give an opinion on the submitted tenders.

The rules for the selection of the members of the contest committees and the timespan of their work are unclear. The Act does not indicate whether committees will be appointed on an ad hoc basis each time to conduct an individual contest procedure, or whether they will operate for a longer period of time, even for a specified term, in connection with the introduction of rules for excluding their members. In addition, there is no guarantee that the assessment of submitted tenders by persons appointed by competitors to the PBOs taking part in the contest will be impartial. Moreover, the Act does not specify who decides on the result of the contest; as a rule, the public administration body announcing the contest is competent in this respect. ${ }^{27}$

27 p. Kledzik, Działalność organizacji pozarzq̨dowych na rzecz realizacji celów publicznych, Warszawa 2013, p. 168. 


\section{The Announcement of the Results of the Contest Without the Possibility of Appeal}

There are several arguments in favour of the view that the announcement of the results of a contest does not have the attributes of an administrative decision and therefore no appeal may be lodged. First of all, the announcement of the results of the contests is just ordinary information announced by analogy to announcing the contest on the website of the contest announcing body, in the Public Information Bulletin and in the seat of the body, in the place designated for this purpose. In accordance with Article 15(2h) APBAVW, the announcement shall contain at least the following information: (1) the name of the bidder; (2) the name of the public task; and (3) the amount of public funds allocated. Secondly, the Act does not require a justification for the choice of a tender or its rejection. While Article 15(2i) APBAVW allows a statement of reasons to be requested, this provision does not specify the group of entities that may request it. The legislator, using the word "any”, suggests that it may be not only the PBO concerned, but also another natural or legal person who does not have to demonstrate its legal interest. ${ }^{28}$ Moreover, it proves that this right is held by any entity subject to Article 37 of the Constitution of the Republic of Poland to which legal capacity is granted by law $^{29}$; however, it seems that this provision should only apply to entities located outside the public administration. Nevertheless, one may wonder whether this scope is not too broad and whether it should not be limited to include only those participating in the contest.

As regards the announcement of the results of the contest, it should be noted that the expression "in particular" used in Article 15(2h) APBAVW indicates that, although the scope of information to be made available to the public as set out in that provision is obligatory, this catalogue is not closed and the authority may, at its discretion, extend

28 J. Kosowski, Współpraca jednostek samorzqdu terytorialnego z organizacjami pozarzq̨dowymi, Warszawa 2012, p. 128.

29 Cf. K. Gruszecki, Prawo ochrony środowiska. Komentarz, Warszawa 2008, p. 50. 
it, e.g. to include information on the rules and procedure for requesting justification for the selection or rejection of a tender. It seems to be possible, due to the above-mentioned fact, that the stipulated content of the announcement of the contest results is not exhaustive.

Therefore, as far as the current legal situation is concerned, there are no arguments to indicate that the announcement has the attributes of an administrative decision, including the possibility of using a remedy or other provisions aimed at PBO protection. Even if the results of an open contest are announced in an ordinance of mayor or head of the commune, the ordinance is not subject to appeal at the Voivodship Administrative Court. ${ }^{30}$ The authority shall rule by way of an administrative decision only in the situation referred to in Article 152(3) of the Public Finance Act, if it finds that the subsidy has been misused in part or in whole, or has been collected in an excessive amount, and is to be returned to the State budget. No possibility of appeal, and thus of renewed examination by common courts, administrative courts, extrajudicial bodies or a public entity aiming at concluding a contract, brings us close to the issue of hybrid solutions.

The conviction that the only option is a complaint seems to be an extremely weak tool. The basis for regulation within the scope of the discussed legal institution is Art. 63 of the Constitution of the Republic of Poland, under which everyone shall have the right to submit petitions, proposals and complaints in the public interest, in their own interest or in the interest of another person with their consent to public authorities in connection with implementation of their prescribed tasks within the field of public administration. This right applies to the possibility of filing specific requests with public authorities, as well as organisations and institutions. Importantly, this right is not limited to citizens only. According to the constitutional regulation, the institution of complaint can be used by anyone. Apart from public administration bodies, the Polish Constitution included in the regulation of Art. 63 also social organisa-

30 Ruling of the Voivodship Administrative Court of 28 September 2018, case ref. IVS A/Wr 418/18, Legalis no. 1824952. 
tions and institutions, thus providing the citizens with influence on the activities of the entities that perform specific public tasks for the state or local government authorities. However, the Constitution of the Republic of Poland does not regulate the procedure of examining petitions, complaints and proposals, referring in this respect to the ordinary act.

The constitutional regulation on the procedure for examination of petitions, complaints and proposals was expanded in the regulations of the CAP and the Ordinance of the Council of Ministers of 8 January 2002 on the organisation of the receipt and examination of complaints and proposals, issued on the basis of the authorisation contained in the Code. ${ }^{31}$ According to Art. 221 in connection with Art. 2 CAP, the right to submit petitions, complaints and proposals to the state bodies, LGU bodies, bodies of local government organisational units and social organisations and institutions, guaranteed to everyone in the Constitution of the Republic of Poland, is implemented under the principles set forth in the CAP. In other words, Article 221 CAP in $\S 2$ and 3 quotes the provisions of the Constitution. The complaint is undoubtedly an expression of the complainant's dissatisfaction..$^{32}$ A complaint within the meaning of Article 227 CAP should be distinguished from a complaint within the meaning of the provisions of the AACP. According to the position established in the jurisprudence of administrative courts, a complaint which is the subject of the regulation of Section VIII of the CAP is a de-formalised means of defending and protecting the interests of an individual, which do not give rise to a request to initiate administrative proceedings or cannot constitute a basis for a legal action or for a request to initiate court proceedings. Complaints of this kind are dealt with in an independent single-instance simplified procedure, ending with a material and technical act of notifying the complainant of the way in which the case has been dealt with. This mode does not provide

31 Journal of Laws of 2002, no. 5, item 46.

32 M. Wierzbowski, A. Wiktorowska, in: M. Wierzbowski, M. Szubiakowski, A. Wiktorowska, Postępowanie administracyjne - ogólne, podatkowe, egzekucyjne i przed sq̨dami, Warszawa 2004, p. 244. 
for the possibility to act in any further instances, i.e. to initiate an appeal procedure or administrative court proceedings. ${ }^{33}$

Moreover, it is assumed in the jurisprudence that it is inadmissible to lodge a complaint with the administrative court if it is lodged pursuant to Art. 229 CAP, i.e. if the competence to examine it lies with the commune councils, district councils or voivodship assemblies. The complaint shall be dealt with by issuing an appropriate resolution by the competent council. Resolutions of the LGU bodies could be appealed to the administrative court, however, the courts are of the opinion that considering a complaint as admissible would cause the unjustified inequality of entities, for those whose complaint has not been resolved in the form of a resolution would not be entitled to a complaint to the court against the action informing about the manner of resolution. Moreover, the inadmissibility of a complaint to an administrative court in such cases is justified by the fact that resolutions of the decision-making bodies of local government units in the cases of complaints under Section VIII of the CAP are not public administration cases. ${ }^{34}$

\section{Conclusions}

Summarising the deliberations on the procedure of open bidding for performance of a public task and the lack of premises for the application of appeal procedures, it should be emphasized that PBOs have no grounds for procedural activity. It seems that extending the rules in administrative and administrative court proceedings could have a positive impact. De lege lata the circumstances may limit the pace of development of

33 Judgment of the Supreme Administrative Court of 1 December 1998, III SA 1636/97, Lex no. 3713; Ruling of the Voivodship Administrative Court in Warsaw of 7 December 2004, II SAB/Wa 193/04.

34 Ruling of the Supreme Administrative Court of 12 April 2001, I SA 2668/00, Lex no. 54426; Ruling of the Voivodship Administrative Court in Gorzów Wielkopolski of 16 February 2010, II SA/Go 37/10, Lex no. 621902; Ruling of the Voivodship Administrative Court in Kraków of 22 February 2019, III SA/Kr 67/19, Lex no. 2624879; Judgment of the Supreme Administrative Court of 28 April 2010, case ref. I OSK 209/10. 
civil society and thus hamper the process of development and implementation of public tasks. Therefore, as a de lege ferenda conclusion, it can be argued that PBOs should be given additional powers.

Finally, it is worth pointing out that the procedure of an open contest is in itself a positive and well-founded phenomenon. Apart from creating competition between PBOs, it is crucial to create an atmosphere of openness and transparency in decision-making processes in public matters. Undoubtedly, the evaluation of a project should be based on free, fair and impartial assessment, and not on an arbitrary one, as its limits are set by the principles of equal access and the transparency of evaluation criteria. The result of such an assessment should include a justification with a particular explanation of the circumstances which gave rise to the final settlement, e.g. on the number of points awarded within the assessment. At each stage of the case, the beneficiary should be given a precise indication of the results of that stage and information with a detailed, clear, reliable and transparent analysis of the evaluations. The information communicated by the public administration body must include the reasons for the evaluation or for disregarding the objection at the next stage, together with their justification. Only then can the administrative court address the allegations of a complaint, get to know the position of the project evaluator, and determine whether such an assessment is lawful. ${ }^{35}$ Certainly, verification of the results of the assessment to ensure that it does not contravene the above-mentioned rules should be allowed. Furthermore, it should be noted that the procedure for conducting the contest does not provide for any renewed assessment of the tenders submitted. It is therefore unacceptable to contest the evaluation of tenders which, if accepted, will lead to the conclusion of a public task contract. ${ }^{36}$

The construction used in this way is alien to the idea of the democratic state of law, because it deprives the PBOs of any protection. On

35 Judgment of the Voivodship Administrative Court in Warsaw of 17 November 2017, V SA/ Wa 1782/17.

36 Judgment of the Voivodship Administrative Court in Bydgoszcz of 24 August 2016, II SA/ Bd 597/16, Lex no. 2152064. 
the one hand, it gives the PBOs right to participate in the creation of public tasks, while on the other, it deprives them of any remedy whatsoever.

\section{References}

Blicharz J., Komentarz do art. 13 ustawy o działalności pożytku publicznego i o wolontariacie, in: Blicharz J., Ustawa o działalności pożytku i o wolontariacie, Lex 2012.

Blicharz J., Komentarz do art. 18a ustawy o działalności pożytku publicznego i o wolontariacie, in: Blicharz J., Ustawa o działalności pożytku publicznego i o wolontariacie, Lex 2012.

Gruszecki K., Prawo ochrony środowiska. Komentarz, Warszawa 2008.

Izdebski H., Ustawa o działalności pożytku publicznego i o wolontariacie. Komentarz, Warszawa 2003.

Kledzik P., Działalność organizacji pozarzq̨dowych na rzecz realizacji celów publicznych, Warszawa 2013.

Kopyra J., Ustawa o działalności pożytku publicznego i o wolontariacie. Komentarz, Warszawa 2005.

Kosowski J., Współpraca jednostek samorzqdu terytorialnego z organizacjami pozarzqdowymi, Warszawa 2012.

Kowal N., Komentarz do ustawy o działalności pożytku publicznego i o wolontariacie, in: Tworzenie i rejestracja organizacji pożytku publicznego, Zakamycze 2005, Legalis.

Kowal N., Tworzenie i rejestracja pożytku publicznego. Komentarz, Kraków 2005.

Olejniczak A., Skutki braku konsultacji programu współpracy z organizacjami pozarzqdowymi i pożytku publicznego, 2016, Legalis.

Pakuła A., W kwestii prywatyzacji organizacyjnych form realizacji zadań publicznych w trybie ustawy o działalności pożytku publicznego i wolontariacie na przykładzie pomocy społecznej, in: J. Blicharz, Prawne aspekty prywatyzacji, Warszawa 2012.

Skiba R., Jak współpracować z administracjq publicznq, Warszawa 2004. 
Staszczyk P., Ustawa o działalności pożytku publicznego i o wolontariacie. Komentarz, Warszawa 2013.

Wierzbowski M., Wiktorowska A., in: M. Wierzbowski, M. Szubiakowski, A. Wiktorowska, Postępowanie administracyjne - ogólne, podatkowe, egzekucyjne i przed sq̨dami, Warszawa 2004.

\section{SUMMARY}

\section{The Settlement of the Bidding Contest for a Public Task Implemented by Non-Governmental Organisations and Public Benefit Entities Without the Possibility of Initiating an Appeal Procedure}

The paper focuses on the financial cooperation of public administration bodies with public benefit organisations (PBOs) in the form of delegation or commissioning statutory public tasks. As a result of cooperation, a contract is concluded, which is preceded by an open bidding contest procedure. Nevertheless, there is no provision in the contest procedure which would constitute a substantive law basis for issuing an administrative decision or taking other actions referred to in art. 3(2)(4) of the Act of 30 August 2002 on the Administrative Court Procedure by a public administration body or an appointed contest committee.

Keywords: public benefit organisations, bidding contest, appeal

Danuta Biniasz-Celka, dam Mickiewicz University in Poznań, Faculty of Law and Administration, Al. Niepodległosci 53, 61-714 Poznań, e-mail: dankacelka@onet.pl.

DOI 10.14746/ppuam.2020.11.14 